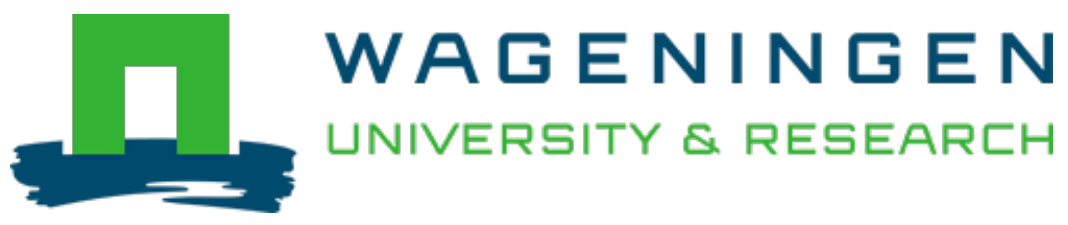

\title{
Social ecological dynamics of tropical secondary forests
}

Forest Ecology and Management

Balvanera, Patricia; Paz, Horacio; Arreola-Villa, Felipe; Bhaskar, Radika; Bongers, Frans et al https://doi.org/10.1016/j.foreco.2021.119369

This publication is made publicly available in the institutional repository of Wageningen University and Research, under the terms of article $25 \mathrm{fa}$ of the Dutch Copyright Act, also known as the Amendment Taverne. This has been done with explicit consent by the author.

Article $25 \mathrm{fa}$ states that the author of a short scientific work funded either wholly or partially by Dutch public funds is entitled to make that work publicly available for no consideration following a reasonable period of time after the work was first published, provided that clear reference is made to the source of the first publication of the work.

This publication is distributed under The Association of Universities in the Netherlands (VSNU) 'Article $25 \mathrm{fa}$ implementation' project. In this project research outputs of researchers employed by Dutch Universities that comply with the legal requirements of Article $25 \mathrm{fa}$ of the Dutch Copyright Act are distributed online and free of cost or other barriers in institutional repositories. Research outputs are distributed six months after their first online publication in the original published version and with proper attribution to the source of the original publication.

You are permitted to download and use the publication for personal purposes. All rights remain with the author(s) and / or copyright owner(s) of this work. Any use of the publication or parts of it other than authorised under article $25 \mathrm{fa}$ of the Dutch Copyright act is prohibited. Wageningen University \& Research and the author(s) of this publication shall not be held responsible or liable for any damages resulting from your (re)use of this publication.

For questions regarding the public availability of this publication please contact openscience.library@,wur.nl 
Mini Review

\title{
Social ecological dynamics of tropical secondary forests
}

\author{
Patricia Balvanera ${ }^{\mathrm{a}}$, Horacio Paz ${ }^{\mathrm{a},{ }^{*}, \text { Felipe Arreola-Villa }}{ }^{\mathrm{a}}$, Radika Bhaskar ${ }^{\mathrm{b}}$, Frans Bongers ${ }^{\mathrm{c}}$, \\ Sofía Cortés ${ }^{\text {a,d }}$, Ek del Val ${ }^{a}$, Eduardo García-Frapolli ${ }^{\text {a }}$, Mayra Elena Gavito ${ }^{\text {a }}$, \\ Carlos E. González-Esquivel ${ }^{a}$, Miguel Martínez-Ramos ${ }^{a}$, Angelina Martínez-Yrizar ${ }^{e}$, \\ Francisco Mora ${ }^{a}$, Julia Naime a,f, Fermín Pascual-Ramírez a, Nathalia Pérez-Cárdenas a , \\ Oscar A. Ugartechea-Salmerón ${ }^{\text {, }}$, Ilyas Siddique ${ }^{\mathrm{a}, \mathrm{g}}$, Ireri Suazo-Ortuño ${ }^{\mathrm{h}}$, Scott M. Swinton ${ }^{\mathrm{i}}$
}

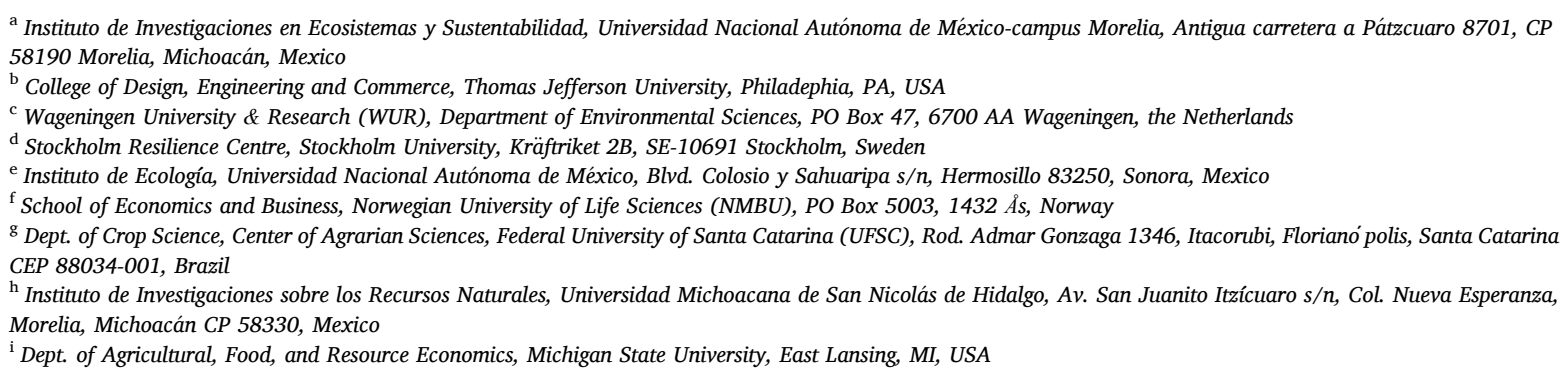

\section{Introduction}

Secondary forests have become a characteristic feature of humanmodified tropical landscapes. These forests, defined as those regenerating spontaneously after clearance of the original old-growth forest (Chazdon, 2014; FAO and UNEP, 2020), are increasingly dominating tropical regions due to the continued advance of the agricultural frontier and the subsequent abandonment of those lands (Wright, 2010). In spite of the problems that the loss of old growth forests poses for global environmental issues, like climate change and biodiversity loss, secondary forests may represent a promise to reconcile tropical forest conservation and human benefits derived from them (Chazdon, 2014). As secondary forests develop, biodiversity, ecosystem functions, and ecosystem services are recovered, providing resources for the livelihoods of local inhabitants such as timber, forage provision for cattle, and firewood (Cortés-Calderón et al., 2021) as well as benefiting global stakeholders (Matos et al., 2019). However, only until recently the scientific community and society in general have become aware of the relevance of advancing knowledge on tropical secondary forests.

Unique insights on the dynamics of tropical secondary forests have emerged from their long-term monitoring across the tropics. One of these monitoring initiatives, the MABOTRO-RESERBOS program, was established in 2004 and has provided since a wealth of understandings on the ecological aspects of forest recovery and the social contexts it occurs. The project has concentrated on two contrasting sites in Mexico: a wet forest site in the Lacandon forest, and a dry forest site on the Pacific Coast. The first part of the project named MABOTRO (after Manejo de Bosques Tropicales, in Spanish), was implemented in 2004-2008 and focused on characterizing the patterns of secondary growth and the processes underlying them. The second part named RESERBOS (Recuperación de Biodiversidad, Funciones y Servicios en Bosques Tropicales, by its initials in Spanish), was implemented 2009-2020 and concentrated on the evaluation of the recovery of ecological functions and ecosystem services, as well as the advance of a deeper understanding of the socioeconomical context and drivers under which forest regeneration occurs.

This special issue on social ecological dynamics of tropical secondary forests provides an overview of the insights gained from the MABOTRORESERBOS program. In this introductory editorial paper, we start by describing the project, its conceptual framework and overall products. Then we explore the specific social-ecological conditions that have fostered secondary forests, with emphasis on those in Mexico. Then we assess what we have learned about the recovery of biodiversity and ecosystem functions along secondary succession. Furthermore, we review key insights that emerged for the management of tropical forest landscapes. We then highlight the tools that have been critical to attain the above insights. To finalize, we discuss how this special issue contributes to a wide literature on tropical forest management.

\footnotetext{
* Corresponding author.

E-mail address: hpaz@cieco.unam.mx (H. Paz).
} 


\section{Long-term monitoring of contrasting tropical secondary} forests: the MABOTRO-RESERBOS project

Interdisciplinary place-based long-term approaches provide unique insights on the ecology and management of tropical secondary forests by small holders. Understanding the societal drivers and motivations associated to these forests (Tauro et al., 2018), the ways in which they are managed (Monroy-Sais et al., 2016; Sánchez-Romero et al., 2021), and the dynamics of their biodiversity (Gavito et al., 2021a; Marroquín-Páramo et al., 2021; Martínez-ramos et al., 2018; PérezCárdenas et al., 2021) ecosystem functions and services (CortésCalderón et al., 2021; Gavito et al., 2021b; Siddique et al., 2021) requires the intertwining of a range of social and ecological disciplines. The long-term monitoring of secondary forest plots, with different management histories and landscape contexts, provides a wealth of information on these dynamics. By emphasizing the importance of sitebased social ecological drivers and conditions for such dynamics, robust ecological data can be linked to the enabling conditions and obstacles faced by forest managers. We focus on smallholders who manage plots often smaller than 2 ha. Small holders contribute at least $30 \%$ of global agriculture and $80 \%$ of that in Latin America, but face poverty and food insecurity (Ricciardi et al., 2018). We provide key insights that allow us to understand their decisions and needs.

A visionary project was created back in 2004 due to the convergence of particularly favorable enabling circumstances. Long-term ecosystem research in the Pacific Coast of Mexico was kickstarted by the National Autonomous University of Mexico (UNAM) around 1980, with a strong emphasis on the ecosystem ecology and the management of the tropical dry forest in the Pacific Coast of Mexico, with an increasingly interdisciplinary social-ecological perspective (Maass et al., 2005). Analogous research initiatives were also launched by UNAM in the tropical humid areas of the Lacandon forest in 1985, focused on the dynamics of the vegetation, and involved a large international collaboration involving the University of Connecticut (USA) and Wageningen University (The Netherlands) aimed at understanding tropical humid secondary forest dynamics since 1994 (Chazdon et al., 2007; Norden et al., 2015). In 2004, the Mexican science agency, the
Consejo Nacional de Ciencia y Tecnología (CONACYT, by its initials in Spanish), opened its first call ever for interdisciplinary projects aimed at addressing environmental issues. Since then, the MABOTRO-RESERBOS program built from those favorable circumstances until today (MartínezRamos et al., 2012). The two sites are now part of the 2ndFOR network, a large network of tropical secondary forests research encompassing around 75 sites, 85 researchers from 16 countries (https://sites.google. $\mathrm{com} /$ view/2ndfor/about-us?authuser=0). Several lateral collaborations have been established with a variety of adjacent projects funded directly to the different co-authors of this editorial and the special issue.

The scope and research questions of the projects, originally focused on the contrasting dynamics of tropical dry and moist secondary forests, have expanded over the past two decades to a social-ecological perspective. The choice of two very contrasting forests, a moist one in the Lacandon Forest, Chiapas (Chajul), and a dry one in the Pacific Coast of Mexico, Jalisco (Chamela) resulting from the above historical process, strategically allowed us to assess the role of biophysical drivers on tropical secondary forest dynamics. As the project evolved, we increasingly paid attention to the role of management legacies and landscape context on such dynamics (Pérez-Cárdenas et al., 2021; Wies et al., 2021). Such efforts also led to a growing emphasis on the tradeoffs emerging from secondary succession, especially on the ecosystem services provided both to local smallholders and to the planet at large (Mora et al., 2016; Naime et al., 2020). The exploration of the enablers and constraints that individual smallholders face in their management decisions, led to the need to consider underpinning drivers at the global and local level (Fig. 1).

The MABOTRO-RESERBOS program has produced a very rich body of knowledge on the social-ecological dynamics of tropical secondary forests. As many as 94 papers and 81 dissertations (undergraduate, masters and doctoral) have been published by the programs since 2004 (Fig. 2). While an important fraction of the productivity has focused on the ecological aspects of secondary succession and projections of forest recovery (structure and function), social-ecological approaches have been increasingly incorporated.

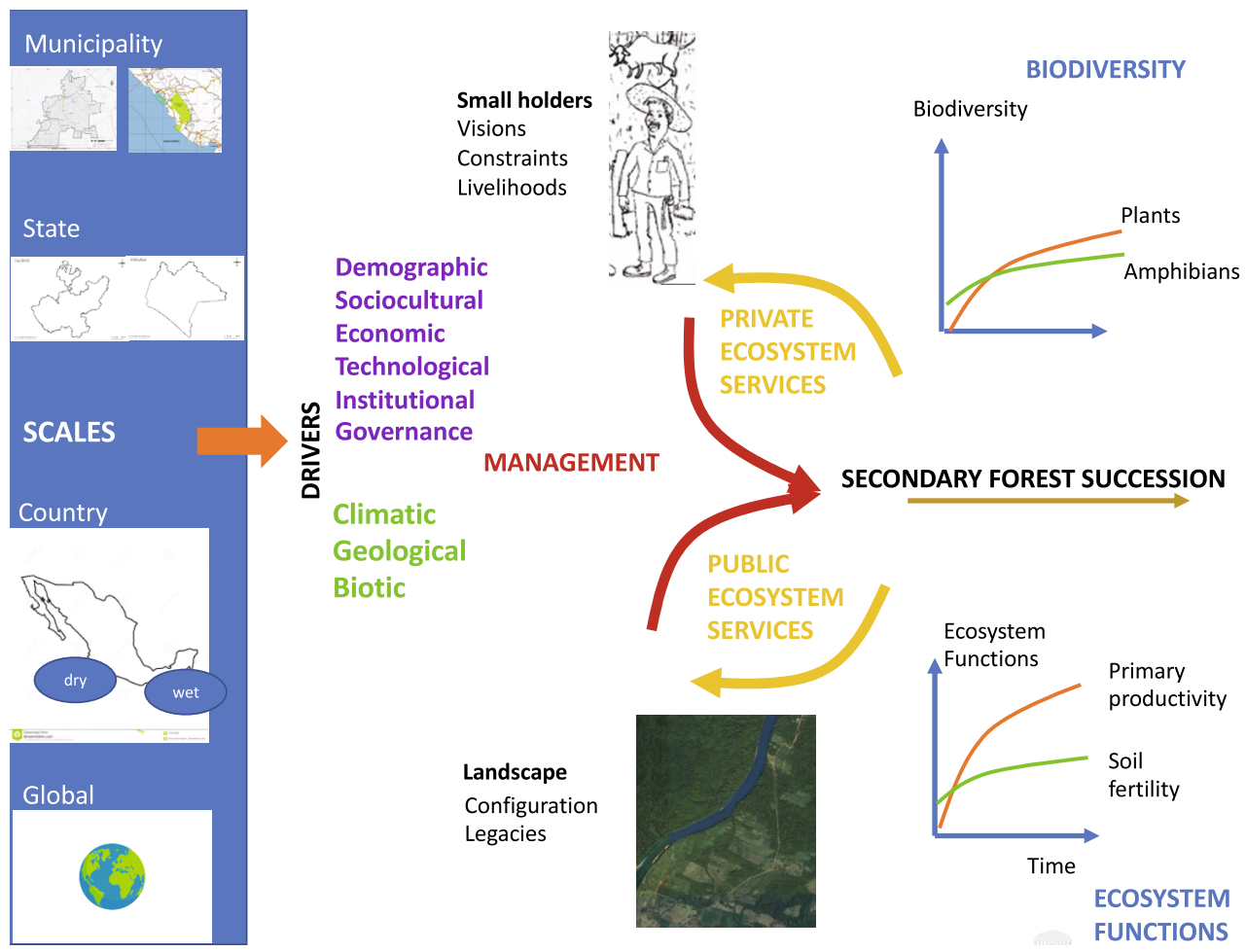

Fig. 1. The conceptual framework of the RESERBOS project. Secondary forest succession is influenced simultaneously by drivers at global to local scales. These drivers can be anthropic, associated with economic, governance or institutional factors, among others (blue) or environmental, such as biotic, geological or climatic factors (green). In addition to these, successional forests are also influenced by management, which may be mostly communal (local) but also occurs at landscape scales. These drivers and management can interact to define the recovery of biodiversity in successional forests, as well as ecosystem functions and services. These services can benefit only the owners of the land, or be private, or benefit many stakeholders, such as those that are global. (For interpretation of the references to colour in this figure legend, the reader is referred to the web version of this article.) 


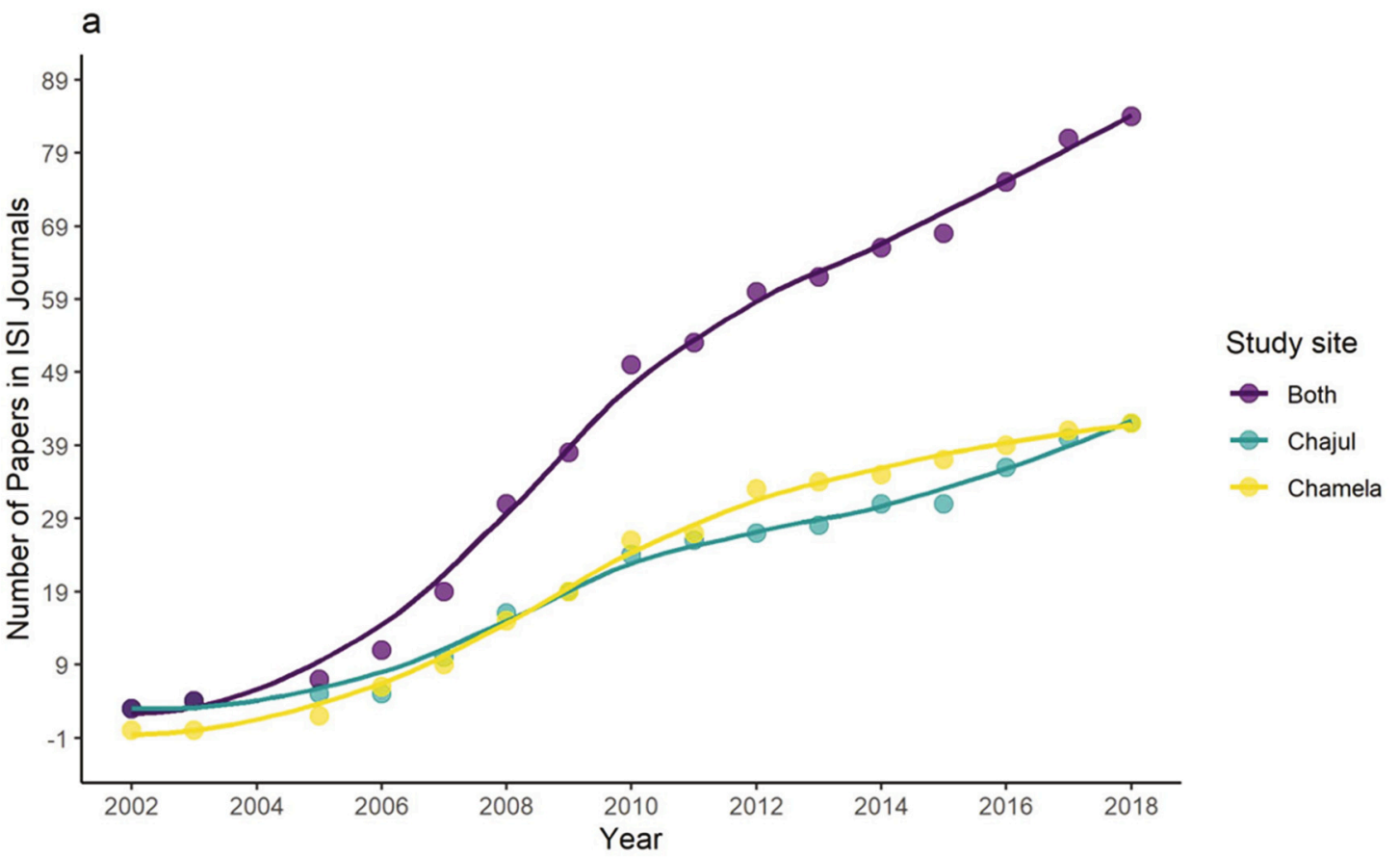

b
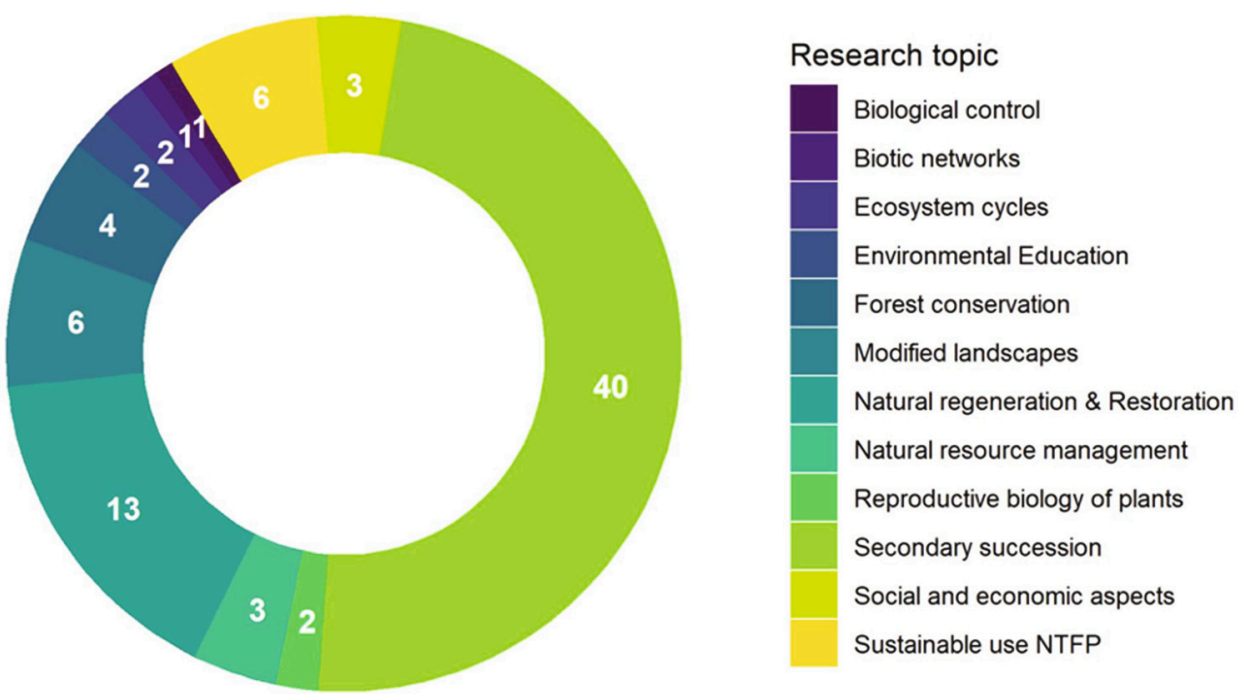

Fig. 2. Scientific productivity of the MABOTRO-RESERBOS program on the social ecological dynamics of two secondary tropical forests of Mexico. Chamela is a dry forest site located in the Pacific Coast of Mexico and Chajul is a humid forest site in the Lacandon area. (a) Cumulative production of articles in ISI journals; (b) Areas of knowledge addressed by these papers, ranging from a range of ecological aspects to social ecological ones.

\subsection{Landscape dynamics of tropical secondary forests and critical drivers}

The creation of ejidos and the policies to develop tropical regions have driven the dynamics of Mexico's tropical forests. The secondary tropical forests of Chamela and Chajul sit within ejidos, which were originally (the onset of the 20th century in Mexico) conceived as semi communal land tenure regimes. Until the Mexican Revolution of the 1910s, land ownership in the country was highly concentrated, with $97 \%$ of rural land owned by only 830 people (Villa-Issa, 1990). The national government began widespread land redistribution in the 1930s, initially in the more densely settled central highlands. From 1940 to the early 1970s, the federal government invested in transportation and irrigation infrastructure, and agriculture prospered (Villa-Issa, 1990). The governmental program "March to the Sea" in 1953-58 redistributed rural land to extend settlement in western states (Castillo et al., 2005), creating the ejidos near the Chamela dry forest research site. A later National Program of Deforestation and Livestock Production (Programa Nacional de Desmontes y Ganaderización, 1960-74) promoted the expansion of livestock production on improved pastures (Castillo et al., 2005). The state of Chiapas, where the Chajul site is located, experienced an important migration wave in the early 1980s of people escaping from the civil war in Guatemala (Castillo and Toussaint, 2015). 
The state-level Plan Chiapas of 1983-86 sought to secure the border with Guatemala by distributing land to create new population centers and encouraging agricultural, timber, and fishing production, including the ejidos in the Marqués de Comillas municipality where the Chajul rainforest research site is located. The policies that distributed forested land to ejidos during this period triggered major deforestation to enable crop and livestock production. Yet at the same time, the semi-communal nature of the ejidos contributed to the maintenance of some forested lands under communal management.

National policies to subsidize industrial agriculture have undermined the economy of small holders and led to the regrowth of tropical secondary forests. Starting in the 1980s, the decline of traditional maize and cattle agriculture accelerated as the Mexican government actively integrated into the global economy by joining major global trade pacts (General Agreement on Tariffs and Trade [GATT]/World Trade Organization [WTO]) in 1986 and the North American Free Trade Agreement in 1994). Exposure to competition from highly efficient and subsidized U.S. agriculture reduced prices, undermining Mexico's traditional grain crop and beef cattle production sector (Villa-Issa, 2008). Many rural people responded by emigrating to cities or to the United States. The new Agrarian Reform Article 27 of 1992, which allowed ejido members to sell their land, probably accelerated this trend. Ecologically, rural emigration enabled the regrowth of secondary forests in both the Chamela and Chajul regions.

Policies to protect biodiversity but also to privatize ejidos have resulting in mixed impacts on tropical forests. The Mexican government protected tracts of remaining forest by creating biosphere reserves in Montes Azules near Chajul (Carabias et al., 2015) and in Chamela-Cuixmala in 1993 (Maass et al., 2005). Since 2000, growing concern over climate change and loss of natural resources has prompted the national program of Payment for Ecosystem Services (Perevochtchikova and Beltrán, 2012) and the United Nations program to reduce emissions from deforestation and forest degradation (REDD+) (Morales-Barquero et al., 2014). At the same time, decisions at the ejido level have become more and more individual (Schroeder and Castillo, 2013), as a result of the weakened ejidal governance of common pool resources due to the legal reforms in the early 1990s. The tensions between individual and communal interests, and the tradeoffs among local and global ecosystem services and stakeholders are driving the current decisions to either keep successional dynamics or transform land back to agriculture (Lazos-Chavero et al., 2016).

Tropical secondary forests are increasingly dominating the tropical landscapes. Young secondary forests in Chajul and Chamela result from the relatively recent colonization (Fig. 3). Farmers from different parts of the country established there in the $70 \mathrm{~s}$, and they transformed these forests extensively into pastures and croplands (Castillo et al., 2005; de Vos, 2002). Secondary forests have formed as part of the slash and burn agricultural cycle, following an accelerated increase. A 30-years lapse analysis (1970-2010) shows that by 2010, in the Chamela region, the dominant land cover was secondary forest $(38 \%$, 2010 s) in place of old growth forest $(62 \%, 70 \mathrm{~s})$, which went down to $25 \%$ (2010s). Pastures have steadily increased over the same period and changed from $11 \%$ to $23 \%$ of the land cover. The secondary forest has increased from $20 \%$ to $42 \%$. In Chajul, in the 70 s, only two land cover

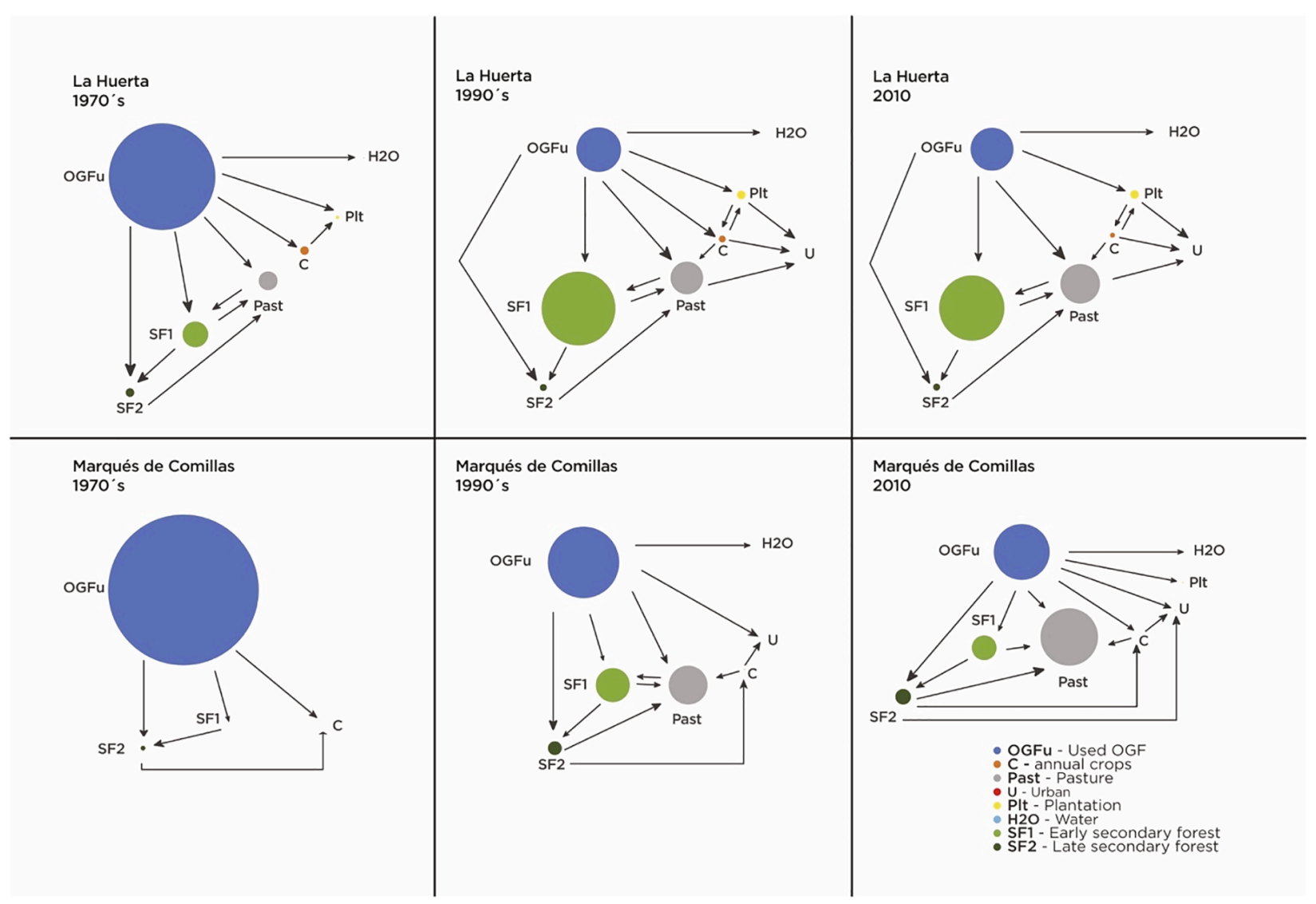

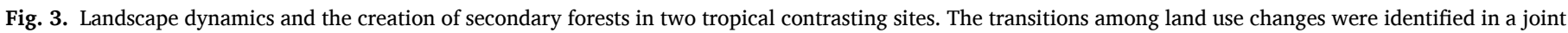

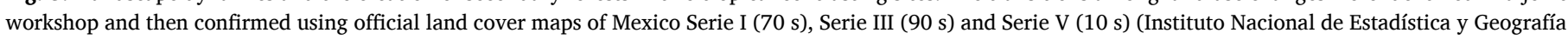

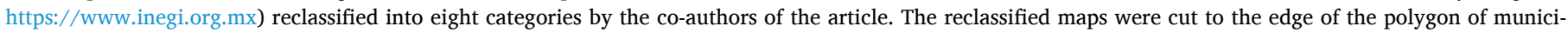

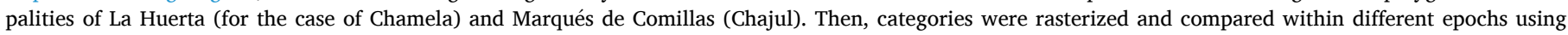

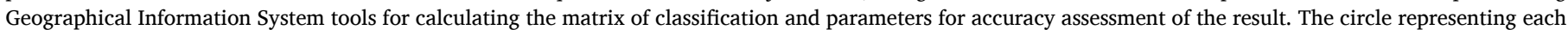
land cover type is proportional to the area it occupies in the municipalities. 
were reported: old growth forest (97\%) and late secondary forest (3\%). Old growth forests have been reduced to $36 \%$, and pastures are now the dominant (37\%) land cover. Secondary forest (early and late) increased up to $26 \%$ (2010s) with minor changes observed from late secondary forest to pasture.

Contrasting biophysical conditions drive moist and dry secondary forest succession dynamics. The total amount of rainfall and its temporal patterns strongly differ between the two studied forests. Abundant rainfall $(3000 \mathrm{~mm})$ and relatively constant humidity contribute to a dense and moist forest in which the tropical forests as well as crops and pastures develop rapidly and competition for light is a major driver (Martinez-Ramos et al., 2009). Instead, scarce rainfall (800 $\mathrm{mm}$ ) with up to 6 months of severe drought and a strong interannual variability (Maass et al., 2018), contribute to short and slow growing forests, and severely limits crop and cattle yields. Geology, topography and soils also play a major role in producing heterogeneous conditions in terms of water and nutrient availability in both sites, and therefore vegetation structure (Jaramillo et al., 2003; Navarrete-Segueda et al., 2018).

\section{Recovery of biodiversity and ecosystem processes along secondary succession}

Recovery rates are highly heterogeneous among groups of organisms and functions. Within the MABOTRO-RESERBOS program, the simultaneous monitoring of multiple groups of organisms besides plants, namely soil microbes, insects, amphibian, reptiles, birds, bats and terrestrial mammals, constitutes a unique effort towards understanding integrative recovery rates in secondary forests in wet and dry regions. As expected, recovery rates are highly heterogeneous among groups of organisms and sites. In the dry forest site, microbes (CarrilloSaucedo et al., 2018; Gavito et al., 2021a), lepidopterans (Hernández et al., 2014) reptiles, anurans (Marroquín-Páramo et al., 2021; SuazoOrtuño et al., 2015a) and birds (Martínez-Ramos et al., 2012) showed a community structure that hardly varies across succession. In contrast, species diversity of beetles declined (Manrique-Ascencio, 2010), while that of trees (Mora et al., 2015) and bats (Avila-Cabadilla et al., 2009) increased along succession, approaching the values observed in the oldgrowth forest in less than 15 years. Similarly, in the wet site, the species diversity of most studied groups (trees, ants, amphibians, reptiles, bats and terrestrial medium-mammals) increased during the first 20 years of succession, approaching the values observed in the old-growth forest (de la Peña-Cuéllar et al., 2012; Rocha-Ortega et al., 2018; van Breugel et al., 2006). The rapid recovery of secondary tropical forests has led to the hypothesis that low habitat differentiation may allow for the conservation of rich animal communities in landscapes (Boege et al., 2019; Suazo-Ortuño et al., 2015b). However, the finding that resilience to repetitive hurricanes greatly differs among some of these groups (Marroquín-Páramo et al., 2021), and the fact that other groups of animals as bats, exhibit large sensitivity to human and natural disturbances (AvilaCabadilla et al., 2009), suggest that opportunities for conservation of animal communities in secondary landscapes may be idiosyncratic to different groups, as in fact a recent meta-analysis has shown (AcevedoCharry and Aide, 2019). A wide disparity of recovery rates has also been observed among ecosystem functions. Intriguingly while above-ground carbon stocks, soil organic matter, microbial activity and microclimate either resist or recover quickly in the dry forest site (within 15-30 years), some key nutrients, such as soil $\mathrm{P}$, recover very slowly and have not recovered after 35 years (Gavito et al., 2021b; Mora et al., 2018). Because soil $\mathrm{P}$ is one of the most limiting factors in tropical forests, its slow pace is expected to slow down the recovery of diverse soil and vegetation processes during secondary succession.

Tropical secondary forests rapidly recover biomass, woody plant richness, key soil and above ground functions, but the recovery of composition is rather slow. Whether the recovery of secondary forests occurs rapidly or not is a crucial question for the conservation of tropical forests and biodiversity under anthropized landscapes (Chazdon, 2014). Findings from our project coincides with others indicating that key components of vegetation structure, such as species richness, standing biomass, and key functions such as primary productivity and soil organic matter tend to recover within the first 25 years of succession in both dry and humid areas (Lohbeck et al., 2012; Poorter et al., 2016; Rozendaal et al., 2019; Mora et al., 2018; Gavito et al., 2021a,b; Pérez-Cárdenas et al., 2021). This clearly contrasts to species composition projections which span several centuries, according to a multi-site study across the Neotropics (Rozendaal et al., 2019). In principle, these results suggest that an important fraction of old-growth forest specialists do not contribute much to the ecosystem functions, particularly to those related to carbon cycling. The role of biodiversity on the recovery of ecosystem functioning is discussed later in this paper.

The successional dynamics is contrasting between the dry and the wet forests. The forest recovery rates are likely affected by rainfall gradients. For example, when comparing 48 forests regions across the Neotropics Poorter et al. (2016) and Rozendaal et al. (2019) demonstrated that above-ground biomass and tree species richness, accumulate faster in regions with less water deficit, although the proportional recovery relative to old-growth forests is likely the same in both environments. Recovery of species diversity appears to be fostered in dry forests by resprouting of remnant individuals (Martínez-Ramos et al., 2021), but also by the smaller regional species pool relative to those of wet forests (Rozendaal et al., 2019).

Plant community structure seems to be driven by biotic and abiotic filters whose importance varies depending on local forest factors. Understanding the mechanisms driving plant species assembly along secondary succession provides important bases for the sustainable management of forest ecosystems and their conservation in benefit of local and non-local people (Martínez-Ramos et al., 2021). Studies in our wet forest site support the hypothesis that at early successional stages abiotic filters are more important in shaping the woody community structure, while the opposite occurs towards advanced succession (Lohbeck et al., 2015b, 2013). However, two studies conducted in our dry forest site have yielded inconsistent results. Clumped phylogenetic arrays have been found at early stages and over dispersion in later ones (Maza-Villalobos et al., 2020), as well as a wide variance in the dispersion arrays depending on the particular functional trait considered, overall suggesting no clear shift of drivers across succession, or different mechanisms operating at wet or dry forests (Maza-Villalobos et al., 2020; Bhaskar et al., 2014). In this issue, Martínez-Ramos et al. (2021) make an important step forward by disentangling the patterns of species phylogenetic dispersion across life stages in a dry forest. Of particular interest is the discovery that the assembly of the woody community along succession resulted from a combination of abiotic filtering processes, operating mostly on seedlings, and biotic filtering processes, operating mostly on resprouts. This novel study is the first one to demonstrate that two routes of recruitment (seedlings and resprouts) can determine differences in the assembling mechanisms between the dry and wet forests.

Biodiversity and ecosystem functioning recover in parallel to plant standing biomass and other structural variables. A principal hypothesis to explain how biodiversity and ecosystem functions recover along secondary succession is that as species are replaced through time and organisms with different life histories accumulate, complementarity or higher structural complexity increase, enhancing the cycling efficiency and the resilience of the forest (Ali et al., 2016; Grigulis et al., 2007; Lavorel et al., 2011). Alternative hypotheses propose that ecosystem processes are driven by changes in the dominant functional traits (not their diversity), or simply by the progressive accumulation of plant biomass, independently of species traits (Finegan et al., 2015; Lohbeck et al., 2015a, 2016. Joint efforts by MABOTRO - RESERBOS and 2ndFOR have shed important advances to test these hypotheses. First, functional diversity clearly increases parallel to species richness along succession in the wet forest of Chajul (Lohbeck et al., 2012), but less clearly in the dry 
forest of Chamela (Bhaskar et al., 2014). Second, dominant woody plant strategies effectively change across secondary succession but in opposing directions depending on the forest type, from acquisitive to conservative species in the wet forest, and the other way around in the dry forest (Lohbeck et al., 2013; Pineda-García et al., 2015; Poorter et al., 2019). From these patterns of functional composition, potential changes in ecosystem processes have been invoked regarding functions such as carbon fixation and stocks across succession. Third, explicit tests for the three alternative hypotheses (functional diversity, functional dominance and biomass) linking biodiversity and ecosystem function across secondary succession, detected that in both wet and dry forest regions, variables involved in carbon cycling, as biomass accumulation and decomposition rates are affected by plant biomass, but not by functional dominance, nor by functional diversity (Chazdon et al., 2016; Lohbeck et al., 2015b; Mora et al., 2018). In the present special issue, two papers contribute with direct measurements of key soil ecosystem processes and productivity in our dry forest, detecting more complex patterns of co-variation between traits and processes along succession than previously expected. Gavito et al. (2021a) find that litter quality is not associated to successional age, while contrary to expected, litter decomposition rates show only a weak age signal, decreasing from pastures and early sites to mature forests. The authors conclude that litter decomposition rates in the dry forest are quite resilient to forest cover type, being forest age a poor predictor. On the other hand, Siddique et al. (2021), tested an a priori model of causal relationships between multiple vegetation variables and three ecosystem variables (plant biomass, litter carbon stock, soil compaction), incorporating the main drivers reported in the literature to date. Their findings indicate that species richness and turnover, but not functional diversity, directly or indirectly affect the three ecosystem variables considered. This opens the question on which traits should be used to capture the diversity of ways of living in species rich tropical communities. To our knowledge, still very few attempts have been done to test the links between biodiversity and ecosystem function during secondary succession in the tropics (Finegan et al., 2015; Lohbeck et al., 2015a, 2016; Prado-Junior et al., 2016; van der Sande et al., 2017; Mora et al., 2018; Teixeira et al., 2020; Siddique et al., 2021), making it difficult to derive general patterns.

More studies are needed to disentangle the causal link between plant functional diversity and ecosystem functioning in secondary forests. An interesting research direction points to the role of functional diversity at the landscape level. While a few dominant species may control ecosystem processes within particular forest patches, the spatial and temporal heterogeneity of dominants among patches may play a role on forest resilience and stability (Lohbeck et al., 2016). Yet, a counterintuitive result is that response diversity, i.e. the diversity of species responses to disturbances like hurricanes, showed a negative correlation with rates of recovery of basal area after a hurricane impact (Bhaskar et al., 2018). Better conceptual models considering synergies and feedbacks, and the measurement of critical traits and variables are most needed. In addition, efforts to understand the linkage between biodiversity and ecosystem functioning other than nutrient and carbon cycling, for example water cycling, are mostly pending. Work on water relations of multiple species have been conducted, both in wet (Schönbeck et al., 2015) and in dry forests (Méndez-Alonzo et al., 2013; Pineda García et al., 2013), but upscaling to community and systems level is largely unexistent.

\section{Managing tropical secondary forest succession}

Landscape configuration is a key determinant of biodiversity and functional forest recovery. The spatial context where secondary forest plots develop has been historically recognized as a relevant driver of forest recovery (Pickett et al., 1987; Meiners et al., 2015). Secondary succession at any given plot may follow multiple recovery pathways subject to multiple factors spatially structured in the landscape (Arroyo-
Rodríguez et al., 2015; Maza-Villalobos et al., 2011a,b; Mora et al., 2015). The forest composition of the surrounding area (forest cover relative to non-forested area) has been proposed as a key driver, because it affects propagule availability and seed arrival to successional sites, impacting thus temporal trajectories of species recruitment, turnover and functional composition (Fahrig, 2013). By superimposing a landscape composition gradient over the classic chronosequence approach (followed by most of the studies in the present issue), Pérez-Cárdenas et al. (2021) supported such hypothesis by detecting that forest proportion positively affects species richness recovery, while pasture cover negatively affects forest standing biomass recovery. Similar effects have also been detected in our wet forest site (Wies et al., 2021), overall suggesting that landscape composition surrounding a given plot of secondary forest impacts its successional pathway. Conceptual models of secondary forest recovery need thus to explicitly incorporate landscape configuration (Crk et al., 2009; Fahrig, 2013; Maza-Villalobos et al., 2011a, 2011b; Mora et al., 2015) to enhance our ability to contribute towards conserving landscape quality as a paramount aspect to enhance forest recovery (Robiglio and Sinclair, 2011) and also to maintain both biodiversity and ecosystem services (Arroyo-Rodríguez et al., 2020).

Management history affects the rate of recovery of secondary forests. Tropical forests frequently recover spontaneously when slashing and burning stops, even if the land is still used for resource extraction or cattle browsing (Trilleras et al., 2015; Zermeño-Hernández et al., 2015; Sánchez-Romero et al., 2021, but see Suazo-Ortuño et al. (2015a, 2015b) for exceptions under extremely degraded soils). Yet, land-use history and intensity can filter out species recruitment, due to landuse legacies (Zermeño-Hernández et al., 2016; Jakovac et al., 2016). The recovery rate of biomass can be predicted from the intensity of forest management in the wet forest (Zermeño-Hernández et al., 2015), and from legacies in species diversity and composition in the dry forest (Romero-Duque et al., 2007). However, studies assessing the relative importance of successional time, landscape composition and land-use legacies on forest regeneration are still scarce (Mora et al., 2015; Robiglio and Sinclair, 2011). In the present issue, Pérez-Cárdenas et al. (2021) tested such factors, and contrary to expectations, found that past land-use intensity only weekly explained vegetation diversity. The observed effect of landscape composition on species richness and aboveground biomass recovery confirms the importance of reconciling forest conservation and agricultural management.

Synergies emerge along secondary succession between functions and ecosystem services. Ecological processes related to plant growth and carbon productivity can rapidly recover through natural regeneration in young forests of relatively high plant diversity, even lacking many of the old-growth forests specialists (see above). Synergies between species richness, basal area, carbon stocks, and soil properties such as soil penetration along succession have been found (AyalaOrozco et al., 2017; Siddique et al., 2021). In addition, the supply of ecosystem services such as the availability of useful species, microclimate regulation and contributions to climate change mitigation increased, as documented by three papers in this special issue (CortésCalderón et al., 2021; Naime et al., 2020; Siddique et al., 2021). These papers indicate clear synergies between several functions and services that are linked to increases in above ground biomass. Yet, the wide variation in recovery rates of biodiversity components and ecosystem functions across secondary succession, point to the need for indicators of integrative recovery or coupled synergistic functions and components (see below).

Tradeoffs between services are associated to the transformation of old-growth and secondary forests into agricultural land uses, and viceversa. Tradeoffs between regulating services, such as carbon capture and storage that benefit many stakeholders beyond the managed site, and provisioning services that support the livelihoods of local farmers are documented in this issue (Cortés-Calderón et al., 2020; Naime et al., 2020). Main tradeoffs occur between services that provide private benefits at local scales for the plot managers, such as the provision of 
forage for cattle, which under current management strategy entails forest clearance to foster the growth of light-demanding grasses, and services that provide global public services, such as carbon storage and biodiversity conservation (Trilleras et al., 2015; Mora et al., 2016, 2018). Additional tradeoffs occur at landscape scales between economic activities, such as luxury tourism and agricultural production, as both depend on water availability and both sustain local livelihoods (FloresGutierrez et al., 2020; Maass et al., 2005; Riensche et al., 2015). These tradeoffs are nevertheless not perceived homogenously among local farmers. Initial settlers of our dry site, who were supported by governmental incentives to transform the forests into agriculture in the 1960s, mostly emphasize provisioning ecosystem services, while those born in areas adjacent to the forests, who had more access to education, more diverse livelihoods and had been influenced by the presence of academics in the region, recognize the importance of regulating and cultural services (Tauro et al., 2018).

Tradeoffs among functions, services and stakeholders can be overcome through agroecological management that take stock of existing synergies. Most conventional management schemes based on intensive management of pastures have exacerbated tradeoffs between pastures that are devoid of woody species and conserved forests in reserves (Lazos-Chavero et al., 2016; Mora et al., 2016). Yet, this special issue identifies ways to take advantage of the multiple useful species and the key regulating ecosystem services that are provided by older secondary forests (Cortés-Calderón et al., 2021; Naime et al., 2020; Sánchez-Romero et al., 2021). Enriching secondary forests with useful species through silvopastoral practices may make the most of successional forests and allow for multiple uses (Sánchez-Romero et al., 2021). Leveraging tradeoffs among ecosystem services by providing a monetary compensation to landholders losing provisioning benefits could be desirable, considering that the opportunity costs are highest in early stages of secondary forest succession (Naime et al., 2020).

\section{Tools to assess and manage tropical secondary forest succession}

Multi-species allometric models and indicators of integrative recovery are key to assess forest dynamics and inform their management. Management actions to accelerate the recovery of ecosystem processes and services urgently depend on the design of innovative tools for rapid assessment of secondary patches. Time under succession is likely not a reliable measure of the recovery process in actively managed landscapes (Chazdon, 2014). Instead, measurable properties that integrate the action of natural regeneration and disturbances, natural and human, are likely more reliable indicators of forest state of recovery. Two papers in this special issue present progress on the design or refinement of better tools. First, Bojórquez et al. (2020) developed multi-species allometric models to estimate standing biomass and thus carbon stocks in secondary forests in a tropical dry region. Specifically developed for secondary forests (see Chave et al., 2014), this tool predicted local carbon stocks better than the most commonly used global models. On the other hand, Gavito et al. (2021b, this issue) assessed the integrated response of other key ecosystem components as soil and microclimate, and found that standing basal area, is the best indicator, in concordance with previous efforts and studies showing how vegetation, soil and microclimate are strongly linked (Bardgett and Van Der Putten, 2014). Interestingly, Gavito et al. (2021b) discovered that also standing litter biomass is much easier to assess and allows for understanding its synergistic links with other ecosystem components from a point-shot measurement.

\section{Conclusions: the contributions of the MABOTRO-RESERBOS program}

The papers in this special issue on the social-ecological dynamics of secondary tropical forests, together with the MABOTRO-RESERBOS program and the 2ndFOR network, provide unique insights on the social-ecological dynamics of secondary tropical forests. The long-term, interdisciplinary approaches used allowed to integrate multiple disciplines, with multiple funding opportunities and products, into a comprehensive understanding of such dynamics. Yet, while the conceptual framework developed by the team aims at interconnecting the different social-ecological components, most of the contributions of the team and of this special issue dwell on ecological process, on the management of secondary forests, and much less on the drivers of such management.

Our results not only point to the need for reconciling conservation, agriculture and livelihoods, but also provide guidance on how to do it. We present (1) the ecological information about synergies and tradeoffs, (2) the tools to assess recovery, and (3) the policy options that contribute to leverage the tradeoffs of different management alternatives. For example, secondary forests favorable for regeneration could be included in conservation programs for fast recovery of species richness and diversity within landscapes. High potential for carbon storage and sequestration of young secondary forests can be reconciled with the slow recovery of old-growth forest species composition. Promoting agroecological management of multiple ecosystem services in secondary forest landscapes, is a promising strategy to reduce the conflicts between local and global, or particular and social interests on the land. Alternatively, schemes such as payments for ecosystem services could foster the recovery of secondary forests to provide alternative sources of income to local stakeholders while at the same time increasing the much-needed climate services.

The special issue and other results of the projects show how resilient these tropical secondary forests are. Yet, as more intense, and frequent events stemming from climate change, biodiversity is further lost, and land degradation is exacerbated, tipping points may be reached and threaten their long-term maintenance.

This special issue results from unique circumstances that have fostered interdisciplinary collaborations and have resulted in very diverse and comprehensive contributions over the last 18 years. While this understanding has been built on research and education realm, with joint papers, joint theses, and collaborations with several parallel research initiatives, increasingly our emphasis is moving towards more transdisciplinary collaborations, towards the co-development of solutions with local stakeholders. For the tropical dry forest site, a long-term joint monitoring of the social ecological dynamics of the secondary forests with plot owners is well underway. For the tropical moist forest site, collaborations with creatives to enable the co-development of new alternatives towards more sustainable food systems are also well advanced (Kooi and Martinez, 2021). Together with all these new partners and new knowledge developing directions, we add to the world's available information on increased understanding of the processes involved in more sustainable management of the world's secondary forests.

\section{Declaration of Competing Interest}

The authors declare that they have no known competing financial interests or personal relationships that could have appeared to influence the work reported in this paper.

\section{Acknowledgements}

Funding to support the papers in the special issue, the workshops held to develop jointly develop the syntheses in this editorial and to undertake the overall MABOTRO-RESERBOS program as well as the associated collaborations, have been contributed by the Mexican Funding Agency the Consejo Nacional de Ciencia y Tecnologia through the projects SEP-CONACYT 25554, 129740120740, 179045, 47702, through the Forefront Interdisciplinary Research and Education Fund (INREF) of Wageningen University [5160957104 INREF-FOREFRONT], 
through the funding programs of the National Autonomous University of Mexico, Programa de Apoyo a Proyectos de Investigación e Innovación Tecnológica (PAPIIT) including the research projects IN 211114, 211417, 224010, 208012, 207618, and the Programa de Apoyo a Proyectos para Innovar y Mejorar la Educación (PAPIME) including the teaching program PAPIME-210220. We deeply thank the inhabitants of the Chamela and Chajul region for their hospitality and support, the personnel of the Chamela Biological Station, as well as all the collaborators and students of the MABOTRO-RESERBOS program. Angélica Ugartechea Salmerón designed one of the figures.

\section{References}

Acevedo-Charry, O., Aide, T.M., 2019. Recovery of amphibian, reptile, bird and mamma diversity during secondary forest succession in the tropics. Oikos 128, 1065-1078. https://doi.org/10.1111/oik.06252.

Ali, A., Yan, E.-R., Chen, H.Y.H., Chang, S.X., Zhao, Y.-T., Yang, X.-D., Xu, M.-S., 2016. Stand structural diversity rather than species diversity enhances aboveground carbon storage in secondary subtropical forests in Eastern China. Biogeosciences 13, 4627-4635. https://doi.org/10.5194/bg-13-4627-2016.

Arroyo-Rodríguez, V., Melo, F.P.L., Martínez-Ramos, M., Bongers, F., Chazdon, R.L., Meave, J.A., Norden, N., Santos, B.A., Leal, I.R., Tabarelli, M., 2015. Multiple successional pathways in human-modified tropical landscapes: new insights from forest succession, forest fragmentation and landscape ecology research. Biol. Rev. https://doi.org/10.1111/brv.12231.

Arroyo-Rodríguez, V., Fahrig, L., Tabarelli, M., Watling, J.I., Tischendorf, L., Benchimol, M., Cazetta, E., Faria, D., Leal, I.R., Melo, F.P.L., Morante-Filho, J.C., Santos, B.A., Arasa-Gisbert, R., Arce-Peña, N., Cervantes-López, M.J., CudneyValenzuela, S., Galán-Acedo, C., San-José, M., Vieira, I.C.G., Slik, J.W.F., Nowakowski, A.J., Tscharntke, T., 2020. Designing optimal human-modified landscapes for forest biodiversity conservation. Ecol. Lett. 23, 1404-1420. https:// doi.org/10.1111/ele.13535.

Avila-Cabadilla, L.D., Stoner, K.E., Henry, M., Añorve, M.Y.A., 2009. Composition, structure and diversity of phyllostomid bat assemblages in different successional stages of a tropical dry forest. For. Ecol. Manage. 258, 986-996. https://doi.org/ 10.1016/j.foreco.2008.12.011.

Ayala-Orozco, B., Gavito, M.E., Mora, F., Siddique, I., Balvanera, P., Jaramillo, V.J., Cotler, H., Romero-Duque, L.P., Martínez-Meyer, E., 2017. Resilience of soil properties to land-use change in a tropical dry forest ecosystem. L. Degrad. Dev. https://doi.org/10.1002/ldr.2686.

Bardgett, R.D., Van Der Putten, W.H., 2014. Belowground biodiversity and ecosystem functioning, 515 505, 505-511 Nat.. https://doi.org/10.1038/nature13855.

Bhaskar, R., Arreola, F., Mora, F., Martinez-Yrizar, A., Martinez-Ramos, M., Balvanera, P., 2018. Response diversity and resilience to extreme events in tropical dry secondary forests. For. Ecol. Manage. 426, 61-71. https://doi.org/10.1016/j. foreco.2017.09.028.

Bhaskar, R., Dawson, T.E., Balvanera, P., 2014. Community assembly and functional diversity along succession post-management. Funct. Ecol. 28, 1256-1265. https:// doi.org/10.1111/1365-2435.12257.

Boege, K., Villa-Galaviz, E., López-Carretero, A., Pérez-Ishiwara, R., Zaldivar-Riverón, A., Ibarra, A., Del-Val, E., 2019. Temporal variation in the influence of forest succession on caterpillar communities: a long-term study in a tropical dry forest. Biotropica 51, 529-537. https://doi.org/10.1111/btp.12666.

Bojórquez, A., Martínez-Yrízar, A., Búrquez, A., Jaramillo, V.J., Mora, F., Balvanera, P., Álvarez-Yépiz, J.C., 2020. Improving the accuracy of aboveground biomass estimations in secondary tropical dry forests. For. Ecol. Manage. 474, 118384. https://doi.org/10.1016/j.foreco.2020.118384.

Carabias, J., De la Maza, J., Cardenas, R., 2015. Conservación y desarrollo sustentable en la Selva Lacandona: 25 años de actividades y experiencias. Natura y Ecosistemas Mexicano, A.C., Mexico City.

Carrillo-Saucedo, S.M., Gavito, M.E., Siddique, I., 2018. Arbuscular mycorrhizal fungal spore communities of a tropical dry forest ecosystem show resilience to land-use change. Fungal Ecol. 32, 29-39. https://doi.org/10.1016/j.funeco.2017.11.006.

Castillo, A., Magaña, A., Pujadas, A., Martínez, L., Godínez, C., 2005. Understanding the interaction of rural people with ecosystems: a case study in a tropical dry forest of Mexico. Ecosystems 8, 630-643. https://doi.org/10.1007/s10021-005-0127-1.

Castillo, M.A., Toussaint, M., 2015. La frontera sur de México: orígenes y desarrollo de la migración centroamericana. Cuad. Inter.c.a.mbio sobre Centroamérica y el Caribe $12,58-69$.

Chave, J., Réjou-Méchain, M., Búrquez, A., Chidumayo, E., Colgan, M.S., Delitti, W.B.C., Duque, A., Eid, T., Fearnside, P.M., Goodman, R.C., Henry, M., Martínez-Yrízar, A., Mugasha, W.A., Muller-Landau, H.C., Mencuccini, M., Nelson, B.W., Ngomanda, A. Nogueira, E.M., Ortiz-Malavassi, E., Pélissier, R., Ploton, P., Ryan, C.M., Saldarriaga, J.G., Vieilledent, G., 2014. Improved allometric models to estimate the aboveground biomass of tropical trees. Glob. Chang. Biol. 20, 3177-3190. https:// doi.org/10.1111/gcb.12629.

Chazdon, R.L., 2014. Second Growth: The Promise of Tropical Forests. The University of Chicago Press, Chicago https://doi.org/10.728/chicago/9780226118109.001.0001.

Chazdon, R.L., Broadbent, E.N., Rozendaal, D.M., Bongers, F., Zambrano, A.M., Aide, T. M., Balvanera, P., Becknell, J.M., Boukili, V., Brancalion, P.H., Craven, D., AlmeidaCortez, J.S., Cabral, G.A., de Jong, B., Denslow, J.S., Dent, D.H., DeWalt, S.J., Dupuy, J.M., Durán, S.M., Espírito-Santo, M.M., Fandino, M.C., César, R.G., Hall, J.
S., Hernández-Stefanoni, J.L., Jakovac, C.C., Junqueira, A.B., Kennard, D., Letcher, S.G., Lohbeck, M., Martínez-Ramos, M., Massoca, P., Meave, J.A., Mesquita, R., Mora, F., Muñoz, R., Muscarella, R., Nunes, Y.R., Ochoa-Gaona, S., Orihuela-Belmonte, E., Peña-Claros, M., Pérez-García, E.A., Piotto, D., Powers, J.S., Rodríguez-Velazquez, J., Romero-Pérez, I.E., Ruíz, J., Saldarriaga, J.G., SanchezAzofeifa, A., Schwartz, N.B., Steininger, M.K., Swenson, N.G., Uriarte, M., van Breugel, M., van der Wal, H., Veloso, M.D., Vester, H., Vieira, I.C., Bentos, T.V., Williamson, G.B., Poorter, L., 2016. Carbon sequestration potential of second-growth forest regeneration in the Latin American tropics. Sci. Adv. 2 https://doi.org/ 10.1126/sciadv.1501639.

Chazdon, R.L., Letcher, S.G., van Breugel, M., Martínez-Ramos, M., Bongers, F., Finegan, B., 2007. Rates of change in tree communities of secondary Neotropical forests following major disturbances. Philos. Trans. R. Soc. Lond. B Biol. Sci. 362 , 273-289. https://doi.org/10.1098/rstb.2006.1990.

Cortés-Calderón, S., Mora, F., Arreola-Villa, F., Balvanera, P., 2021. Ecosystem services supply and interactions along secondary tropical dry forests succession. For. Ecol. Manage. 482, 118858. https://doi.org/10.1016/j.foreco.2020.118858.

Crk, T., Uriarte, M., Corsi, F., Flynn, D., 2009. Forest recovery in a tropical landscape: what is the relative importance of biophysical, socioeconomic, and landscape variables? Landsc. Ecol. 24, 629-642. https://doi.org/10.1007/s10980-009-9338-8.

de la Peña-Cuéllar, E., Stoner, K.E., Avila-Cabadilla, L.D., Martínez-Ramos, M., Estrada, A., 2012. Phyllostomid bat assemblages in different successional stages of tropical rain forest in Chiapas, Mexico. Biodivers. Conserv. 21, 1381-1397. https:// doi.org/10.1007/s10531-012-0249-7.

de Vos, J., 2002. Una tierra para sembrar sueños. Historia reciente de la Selva Lacandona 1950-2000. Fondo de Cultura Económica, Centro de Investigaciones y Estudios Superiores en Antropología Social, México.

Fahrig, L., 2013. Rethinking patch size and isolation effects: the habitat amount hypothesis. J. Biogeogr. 40, 1649-1663. https://doi.org/10.1111/jbi.12130.

FAO and UNEP, 2020. Forests, biodiversity and people. The State of the World's Forests 2020. FAO, Rome. 2020. https://doi.org/10.4060/ca8642en.

Finegan, B., Peña-Claros, M., de Oliveira, A., Ascarrunz, N., Bret-Harte, M.S., CarreñoRocabado, G., Casanoves, F., Díaz, S., Eguiguren Velepucha, P., Fernandez, F., Licona, J.C., Lorenzo, L., Salgado Negret, B., Vaz, M., Poorter, L., 2015. Does functional trait diversity predict above-ground biomass and productivity of tropical forests? Testing three alternative hypotheses. J. Ecol. 103, 191-201. https://doi.org/ 10.1111/1365-2745.12346.

Flores-Gutierrez, A.M., Mora, F., Avila-Cabadilla, L.D., Boege, K., Del-Val, E., 2020. Assessing the cascading effects of management and landscape on the arthropod guilds occurring in papaya plantations. Agric. Ecosyst. Environ. 293, 106836. https://doi.org/10.1016/j.agee.2020.106836.

Gavito, M.E., Cohen-Salgado, D., Noguez, A.M., Vega-Peña, E.V., 2021a. In-situ local litter decomposition was mainly microbial and differed between pastures and mature forests but not along early succession in a tropical dry forest ecosystem. For. Ecol. Manage. 480, 118636. https://doi.org/10.1016/j.foreco.2020.118636.

Gavito, M.E., Paz, H., Barragán, F., Siddique, I., Arreola-Villa, F., Pineda-García, F., Balvanera, P., 2021b. Indicators of integrative recovery of vegetation, soil and microclimate in successional fields of a tropical dry forest. For. Ecol. Manage. 479, 118526. https://doi.org/10.1016/j.foreco.2020.118526.

Grigulis, K., Robson, T.M., Lavorel, S., Bello, F De, Que, F., 2007. Incorporating plant functional diversity effects in ecosystem service assessments. Proc. Natl. Acad. Sci. 104, 20684-20689.

Hernández, Y., Boege, K., Lindig-Cisneros, R., Del-Val, E., 2014. Lepidopteran herbivory in restored and successional sites in a tropical dry forest. Southwest. Nat. 59, 66-74. https://doi.org/10.1894/F09-JC-67.1.

Jakovac, C.C., Bongers, F., Kuyper, T.W., Mesquita, R.C.G., Peña-Claros, M., 2016. Land use as a filter for species composition in Amazonian secondary forests. Journal of Vegetation Science 27 (6), 1081-1327. https://doi.org/10.1111/jvs.12457.

Jaramillo, J., Kauffman, J.B., Renterı, L., Cummings, D.L., Ellingson, L.J., 2003. Biomass, carbon, and nitrogen pools in Mexican tropical dry forest landscapes. Ecosystems 609-629. https://doi.org/10.1007/s10021-002-0195-4.

Kooi, A., Martinez, M., 2021. Collaboratory kitchen. In: Tsekleves, E., Cooper, R., Spencer, J. (Eds.), Design for Global Challenges and Goals. Routledge, London, p. 268.

Lavorel, S., Grigulis, K., Lamarque, P., Colace, M.-P., Garden, D., Girel, J., Pellet, G., Douzet, R., 2011. Using plant functional traits to understand the landscape distribution of multiple ecosystem services. J. Ecol. 99, 135-147. https://doi.org/ 10.1111/j.1365-2745.2010.01753.x.

Lazos-Chavero, E., Zinda, J., Bennett-Curry, A., Balvanera, P., Bloomfield, G., Lindell, C., Negra, C., 2016. Stakeholders and tropical reforestation: challenges, trade-offs, and strategies in dynamic environments. Biotropica 48, 900-914. https://doi.org/ 10.1111/btp.12391.

Lohbeck, M., Bongers, F., Martinez-Ramos, M., Poorter, L., 2016. The importance of biodiversity and dominance for multiple ecosystem functions in a human-modified tropical landscape. Ecology 97, 2772-2779. https://doi.org/10.1002/ecy.1499.

Lohbeck, M., Lebrija-Trejos, E., Martínez-Ramos, M., Meave, J.A., Poorter, L., Bongers, F., 2015a. Functional trait strategies of trees in dry and wet tropical forests are similar but differ in their consequences for succession. PLOS ONE 10, 1-15. https://doi.org/10.1371/journal.pone.0123741.

Lohbeck, M., Poorter, L., Lebrija-Trejos, E., Nez-Ramos, M.M., Meave, J.A., Paz, H., Perez-Garcia, E.A., Romero-Perez, I.E., Tauro, A., Bongers, F., 2013. Successional changes in functional composition contrast for dry and wet tropical forest. Ecology 94, 1211-1216. https://doi.org/10.1890/12-1850.1.

Lohbeck, M., Poorter, L., Martínez-Ramos, M., Bongers, F., 2015b. Biomass is the main driver of changes in ecosystem process rates during tropical forest succession. Ecology 96, 1242-1252. https://doi.org/10.1890/14-0472.1. 
Lohbeck, M., Poorter, L., Paz, H., Pla, L., van Breugel, M., Martínez-Ramos, M., Bongers, F., 2012. Functional diversity changes during tropical forest succession Perspect. Plant Ecol. Evol. Syst. 14, 89-96. https://doi.org/10.1016/j. ppees.2011.10.002.

Maass, J.M., Balvanera, P., Castillo, A., Daily, G.C., Mooney, H.A., Ehrlich, P., Quesada, M., Miranda, A., Jaramillo, V.J., García-Oliva, F., Martínez-Yrizar, A., Cotler, H., López-Blanco, J., Pérez-Jiménez, A., Búrquez, A., Tinoco, C., Ceballos, G., Barraza, L., Ayala, R., Sarukhán, J., 2005. Ecosystem services of tropical dry forests: insights from long-term ecological and social research on the Pacific Coast of Mexico. Ecol. Soc. 10, art17. https://doi.org/10.5751/ES-01219-100117.

Maass, M., Ahedo-Hernández, R., Araiza, S., Verduzco, A., Martínez-Yrízar, A. Jaramillo, V.J., Parker, G., Pascual, F., García-Méndez, G., Sarukhán, J., 2018. Long term (33 years) rainfall and runoff dynamics in a tropical dry forest ecosystem in western Mexico: management implications under extreme hydrometeorological events. For. Ecol. Manage. 426, 7-17. https://doi.org/10.1016/j. foreco.2017.09.040.

Manrique-Ascencio, C., 2010. Composición y abundancia de la comunidad de coleópteros asociada a la vgetación en un gradiente sucesional del Bosque Tropical Caducifolio en la región de Chamela-Cuixmala, municipio de la Huerta. Universidad Michoacana de San Nicolás de Hidalgo, México, Jalisco.

Marroquín-Páramo, J.A., Suazo-Ortuño, I., Urbina-Cardona, N., Benítez-Malvido, J., 2021. Cumulative effects of high intensity hurricanes on herpetofaunal assemblages along a tropical dry forest chronosequence. For. Ecol. Manage. 479, 118505. https:// doi.org/10.1016/j.foreco.2020.118505.

Martinez-Ramos, M., Anten, N.P.R., Ackerly, D.D., 2009. Defoliation and ENSO effects on vital rates of an understorey tropical rain forest palm. J. Ecol. 97, 1050-1061. https://doi.org/10.1111/j.1365-2745.2009.01531.x.

Martínez-Ramos, M., Balvanera, P., Arreola, F., Mora, F., Manuel, J., Méndez, S.M., 2018 Effects of long-term inter-annual rainfall variation on the dynamics of regenerative communities during the old-field succession of a neotropical. For. Ecol. Manage. https://doi.org/10.1016/j.foreco.2018.04.048

Martínez-Ramos, M., Barragán, F., Mora, F., Maza-Villalobos, S., Arreola-Villa, L.F., Bhaskar, R., Bongers, F., Lemus-Herrera, C., Paz, H., Martínez-Yrizar, A., Santini, B. A., Balvanera, P., 2021. Differential ecological filtering across life cycle stages drive old-field succession in a neotropical dry forest. For. Ecol. Manage. 482, 118810. https://doi.org/10.1016/j.foreco.2020.118810.

Martínez-Ramos, M., Barraza, L., Balvanera, P., Benitez-Malvido, J., Bongers, F., Castillo Álvarez, A., Cuarón, A.D., Ibarra-Manriquez, G., Paz, H., Pérez-Jiménez, A., Quesada Avendaño, M., Pérez-Salicrup, D.R., Sanchez-Azofeifa, G.A., Schondube, J.E., Stoner, K., Alvarado Diaz, J., Boege, K., Del-Val, E., Favila Carillo, M.E., SuazoOrtuño, I., Ávila-Cabadilla, Luis Daniel, Añorve, M.Y.Á., Ramírez, M.C., Mandujano, J.C., Badilla, O.C., La Peña, E.I.D., Domínguez, A.C., Gutiérrez, M.D.C. G., Bonilla, A.P.G., Di Pierro, A.M.G., Durán, B.F., González, W.A.G., Ordoñez, O.H., Kaláscka, M., Lohbeck, M., López-Carretero, A., Ascencio, C.M., Maza-Villalobos, S., Méndez-Toribio, M., Mora-Ardila, F., Muench, C., Guerrero, C.B.P., Pérez, L.F.P., Pérez, M.E.P., García, F.P., Rocha, A.R., Ortega, M.R., Rodríguez-Velázquez, J., Schroeder, N.M., Trilleras-Motha, J., Van Breugel, M., Van Der Sleen, P., Galaviz, E. V., Hernández, I.Z., 2012. Manejo de bosques tropicales: bases científicas para la conservación, restauración y provechamiento de ecosistemas en paisajes rurales. Investig. Ambient. 4, 111-129.

Matos, F.A., Magnago, L.F., Aquila Chan Mirada, C., de Menezes, L.F., Gastauer, M. Safar, N.V., Schaefer, C.E., Da Silva, M.P., Simonelli, M., Edwards, F.A., Martins, S. V., Meira-Neto, J.A., Edwards, D.P., 2019. Secondary forest fragments offer important carbon-biodiversity co-benefits. Glob. Chang. Biol. 26, 509-522. https:// doi.org/10.1111/gcb.14824.

Maza-Villalobos, S., Ackerly, D.D., Oyama, K., Martínez-Ramos, M., 2020. Phylogenetic trajectories during secondary succession in a Neotropical dry forest: assembly processes, ENSO effects and the role of legumes. Perspect. Plant Ecol. Evol. Syst. 43, 125513. https://doi.org/10.1016/j.ppees.2020.125513.

Maza-Villalobos, S., Balvanera, P., Martínez-Ramos, M., 2011a. Early regeneration of tropical dry forest from abandoned pastures: contrasting chronosequence and dynamic approaches. Biotropica 43. https://doi.org/10.1111/j.17447429.2011.00755.x.

Maza-Villalobos, Susana, Lemus-Herrera, C., Martínez-Ramos, M., 2011b. Successional trends in soil seed banks of abandoned pastures of a Neotropical dry region. J. Trop. Ecol. 27, 35-49. https://doi.org/10.1017/S0266467410000611.

Méndez-Alonzo, R., Pineda-García, F., Paz, H., Rosell, J.A., Olson, M.E., 2013. Leaf phenology is associated with soil water availability and xylem traits in a tropical dry forest. Trees - Struct. Funct. 27, 745-754. https://doi.org/10.1007/s00468-0120829-x.

Monroy-Sais, S., Castillo, A., García-Frapolli, E., Ibarra-Manríquez, G., 2016. Ecological variability and rule-making processes for forest management institutions: a socialecological case study in the Jalisco coast, Mexico. Int. J. Commons 10. https://doi org/10.18352/ijc.672.

Mora, F., Balvanera, P., García-Frapolli, E., Castillo, A., Trilleras, J.M., CohenSalgado, D., Salmerón, O., 2016. Trade-offs between ecosystem services and alternative pathways toward sustainability in a tropical dry forest region. Ecol. Soc. 21 https://doi.org/10.5751/ES-08691-210445.

Mora, F., Jaramillo, V.J., Bhaskar, R., Gavito, M., Siddique, I., Byrnes, J.E.K., Balvanera, P., 2018. Carbon accumulation in neotropical dry secondary forests: the roles of forest age and tree dominance and diversity. Ecosystems 21, 536-550. https://doi.org/10.1007/s10021-017-0168-2.

Mora, F., Martínez-Ramos, M., Ibarra-Manríquez, G., Pérez-Jiménez, A., Trilleras, J., Balvanera, P., 2015. Testing chronosequences through dynamic approaches: time and site effects on tropical dry forest succession. Biotropica 47, 38-48. https://doi org/10.1111/btp.12187.
Morales-Barquero, L., Skutch, M., Jardel-Peláez, E.J., Ghillardi, A., Kleinn, C., Healey, J., 2014. Operationalizing the definition of forest degradation for REDD + with applicatino to Mexico. Forests 5, 1653-16681. https://doi.org/10.3390/f5071653.

Naime, J., Mora, F., Sánchez-Martínez, M., Arreola, F., Balvanera, P., 2020. Economic valuation of ecosystem services from secondary tropical forests: trade-offs and implications for policy making. For. Ecol. Manage. 473 https://doi.org/10.1016/j foreco.2020.118294.

Navarrete-Segueda, A., Martínez-Ramos, M., Ibarra-Manríquez, G., Vázquez-Selem, L., Siebe, C., 2018. Variation of main terrestrial carbon stocks at the landscape-scale are shaped by soil in a tropical rainforest. Geoderma 313, 57-68. https://doi.org/ 10.1016/j.geoderma.2017.10.023.

Norden, N., Angarita, H.A., Bongers, F., Martínez-Ramos, M., Granzow-de la Cerda, I., van Breugel, M., Lebrija-Trejos, E., Meave, J.A., Vandermeer, J., Williamson, G.B. Finegan, B., Mesquita, R., Chazdon, R.L., 2015. Successional dynamics in Neotropical forests are as uncertain as they are predictable. Proc. Natl. Acad. Sci. 112, 8013-8018. https://doi.org/10.1073/pnas.1500403112.

Perevochtchikova, M., Beltrán, A.V., 2012. The Federal Program of Payment for Hydrological Environmental Services as an Alternative Instrument for Integrated Water Resources Management in Mexico City, pp. 35-46.

Pérez-Cárdenas, N., Mora, F., Arreola-Villa, F., Arroyo-Rodríguez, V., Balvanera, P., Flores-Casas, R., Navarrete-Pacheco, A., Ortega-Huerta, M.A., 2021. Effects of landscape composition and site land-use intensity on secondary succession in a tropical dry forest. For. Ecol. Manage. 482 https://doi.org/10.1016/j. foreco.2020.118818.

Pickett, S.T.A., Collins, S.L., Armesto, J.J., 1987. Models, mechanisms and pathways of succession. Bot. Rev. 53, 335-371. https://doi.org/10.1007/BF02858321.

Pineda-García, F., Paz, H., Meinzer, F.C., Angeles, G., 2015. Exploiting water versus tolerating drought: water-use strategies of trees in a secondary successional tropical dry forest. tpv124 Tree Physiol.. https://doi.org/10.1093/treephys/tpv124.

Pineda García, F., Paz, H., Meinzer, F.C., 2013. Drought resistance in early and late secondary successional species from a tropical dry forest: the interplay between xylem resistance to embolism, sapwood water storage and leaf shedding. Plant. Cell Environ. 36, 405-418. https://doi.org/10.1111/j.1365-3040.2012.02582.x.

Poorter, L., Bongers, F., Aide, T.M., Almeyda Zambrano, A.M., Balvanera, P., Becknell, J. M., Boukili, V., Brancalion, P.H.S., Broadbent, E.N., Chazdon, R.L., Craven, D., de Almeida-Cortez, J.S., Cabral, G.A.L., de Jong, B.H.J., Denslow, J.S., Dent, D.H., DeWalt, S.J., Dupuy, J.M., Durán, S.M., Espírito-Santo, M.M., Fandino, M.C., César, R.G., Hall, J.S., Hernandez-Stefanoni, J.L., Jakovac, C.C., Junqueira, A.B., Kennard, D., Letcher, S.G., Licona, J.-C., Lohbeck, M., Marín-Spiotta, E., MartínezRamos, M., Massoca, P., Meave, J.A., Mesquita, R., Mora, F., Muñoz, R., Muscarella, R., Nunes, Y.R.F., Ochoa-Gaona, S., de Oliveira, A.A., OrihuelaBelmonte, E., Peña-Claros, M., Pérez-García, E.A., Piotto, D., Powers, J.S., RodríguezVelázquez, J., Romero-Pérez, I.E., Ruíz, J., Saldarriaga, J.G., Sanchez-Azofeifa, A., Schwartz, N.B., Steininger, M.K., Swenson, N.G., Toledo, M., Uriarte, M., van Breugel, M., van der Wal, H., Veloso, M.D.M., Vester, H.F.M., Vicentini, A., Vieira, I. C.G., Bentos, T.V., Williamson, G.B., Rozendaal, D.M.A., 2016. Biomass resilience of Neotropical secondary forests. Nature 530, 211-214. https://doi.org/10.1038/ nature16512.

Poorter, L., Rozendaal, D.M.A., Bongers, F., de Almeida-Cortez, J.S., Almeyda Zambrano, A.M., Álvarez, F.S., Andrade, J.L., Villa, L.F.A., Balvanera, P., Becknell, J. M., Bentos, T.V., Bhaskar, R., Boukili, V., Brancalion, P.H.S., Broadbent, E.N., César, R.G., Chave, J., Chazdon, R.L., Colletta, G.D., Craven, D., de Jong, B.H.J., Denslow, J.S., Dent, D.H., DeWalt, S.J., García, E.D., Dupuy, J.M., Durán, S.M., Espírito Santo, M.M., Fandiño, M.C., Fernandes, G.W., Finegan, B., Moser, V.G., Hall, J.S., Hernández-Stefanoni, J.L., Jakovac, C.C., Junqueira, A.B., Kennard, D., Lebrija-Trejos, E., Letcher, S.G., Lohbeck, M., Lopez, O.R., Marín-Spiotta, E., Martínez-Ramos, M., Martins, S.V., Massoca, P.E.S., Meave, J.A., Mesquita, R., Mora, F., de Souza Moreno, V., Müller, S.C., Muñoz, R., Muscarella, R., de Oliveira Neto, S.N., Nunes, Y.R.F., Ochoa-Gaona, S., Paz, H., Peña-Claros, M., Piotto, D., Ruíz, J., Sanaphre-Villanueva, L., Sanchez-Azofeifa, A., Schwartz, N.B., Steininger, M.K., Thomas, W.W., Toledo, M., Uriarte, M., Utrera, L.P., van Breugel, M., van der Sande, M.T., van der Wal, H., Veloso, M.D.M., Vester, H.F.M., Vieira, I.C.G., Villa, P.M., Williamson, G.B., Wright, S.J., Zanini, K.J., Zimmerman, J. K., Westoby, M., 2019. Wet and dry tropical forests show opposite successional pathways in wood density but converge over time. Nat. Ecol. Evol. 3, 928-934. https://doi.org/10.1038/s41559-019-0882-6.

Prado-Junior, J.A., Schiavini, I., Vale, V.S., Arantes, C.S., van der Sande, M.T., Lohbeck, M., Poorter, L., 2016. Conservative species drive biomass productivity in tropical dry forests. J. Ecol. 104, 817-827. https://doi.org/10.1111/13652745.12543.

Ricciardi, V., Ramankutty, N., Mehrabi, Z., Jarvis, L., 2018. How much of the world's food do smallholders produce ? Glob. Food Sec. 17, 64-72. https://doi.org/10.1016/ j.gfs.2018.05.002.

Riensche, M., Castillo, A., Flores-Díaz, A., Maass, M., 2015. Tourism at Costalegre, Mexico: an ecosystem services-based exploration of current challenges and alternative futures. Futures 66, 70-84. https://doi.org/10.1016/j. futures.2014.12.012.

Robiglio, V., Sinclair, F., 2011. Maintaining the conservation value of shifting cultivation landscapes requires spatially explicit interventions. Environ. Manage. 48, 289-306. https://doi.org/10.1007/s00267-010-9611-2.

Rocha-Ortega, M., Arnan, X., Ribeiro-Neto, J.D., Leal, I.R., Favila, M.E., MartínezRamos, M., 2018. Taxonomic and functional ant diversity along a secondary successional gradient in a tropical forest. Biotropica 50, 290-301. https://doi.org/ 10.1111/btp.12511. 
Romero-Duque, L.P., Jaramillo, V.J., Pérez-Jiménez, A., 2007. Structure and diversity of secondary tropical dry forests in Mexico, differing in their prior land-use history. For. Ecol. Manage. 253, 38-47. https://doi.org/10.1016/j.foreco.2007.07.002.

Rozendaal, D.M.A., Bongers, F., Aide, T.M., Alvarez-Dávila, E., Ascarrunz, N., Balvanera, P., Becknell, J.M., Bentos, T.V., Brancalion, P.H.S., Cabral, G.A.L., CalvoRodriguez, S., Chave, J., César, R.G., Chazdon, R.L., Condit, R., Dallinga, J.S., de Almeida-Cortez, J.S., de Jong, B., de Oliveira, A., Denslow, J.S., Dent, D.H., DeWalt, S.J., Dupuy, J.M., Durán, S.M., Dutrieux, L.P., Espírito-Santo, M.M., Fandino, M.C., Fernandes, G.W., Finegan, B., García, H., Gonzalez, N., Moser, V.G. Hall, J.S., Hernández-Stefanoni, J.L., Hubbell, S., Jakovac, C.C., Hernández, A.J., Junqueira, A.B., Kennard, D., Larpin, D., Letcher, S.G., Licona, J., Lebrija-Trejos, E., Marín-Spiotta, E., Martínez-Ramos, M., Massoca, P.E.S., Meave, J.A., Mesquita, R.C. G., Mora, F., Müller, S.C., Muñoz, R., de Oliveira Neto, S.N., Norden, N., Nunes, Y.R. F., Ochoa-Gaona, S., Ortiz-Malavassi, E., Ostertag, R., Peña-Claros, M., PérezGarcía, E.A., Piotto, D., Powers, J.S., Aguilar-Cano, J., Rodriguez-Buritica, S., Rodríguez-Velázquez, J., Romero-Romero, M.A., Ruíz, J., Sanchez-Azofeifa, A., de Almeida, A.S., Silver, W.L., Schwartz, N.B., Thomas, W.W., Toledo, M., Uriarte, M., de Sá Sampaio, E.V., van Breugel, M., van der Wal, H., Martins, S.V., Veloso, M.D.M., Vester, H.F.M., Vicentini, A., Vieira, I.C.G., Villa, P., Williamson, G.B., Zanini, K.J., Zimmerman, J., Poorter, L., 2019. Biodiversity recovery of Neotropical secondary forests. Sci. Adv. 5, eaau3114. https://doi.org/10.1126/sciadv.aau3114.

Sánchez-Romero, R., Balvanera, P., Castillo, A., Mora, F., García-Barrios, L.E., GonzálezEsquivel, C.E., 2021. Management strategies, silvopastoral practices and socioecological drivers in traditional livestock systems in tropical dry forests: an integrated analysis. For. Ecol. Manage. 479, 2019. https://doi.org/10.1016/j. foreco.2020.118506.

Schönbeck, L., Lohbeck, M., Bongers, F., Ramos, M., Sterck, F., 2015. How do light and water acquisition strategies affect species selection during secondary succession in moist tropical forests? Forests 6, 2047-2065. https://doi.org/10.3390/f6062047.

Schroeder, N.M., Castillo, A., 2013. Collective action in the management of a tropical dry forest ecosystem: effects of Mexico's property rights regime. Environ. Manage. 51, 850-861. https://doi.org/10.1007/s00267-012-9980-9.

Siddique, I., Gavito, M., Mora, F., Godínez Contreras, M.del C., Arreola, F., PérezSalicrup, D., Martínez-Ramos, M., Balvanera, P., 2021. Woody species richness drives synergistic recovery of socio-ecological multifunctionality along early tropical dry forest regeneration. For. Ecol. Manage. 482, 118848. https://doi.org/10.1016/j. foreco. 2020.118848.

Suazo-Ortuño, I., Alvarado-Díaz, J., Mendoza, E., López-Toledo, L., Lara-Uribe, N., Márquez-Camargo, C., Gil Paz-Gutiérrez, J., David Rangel-Orozco, J., 2015a. High resilience of herpetofaunal communities in a human-modified tropical dry forest landscape in Western Mexico. Trop. Conserv. Sci. 8, 396-423. https://doi.org/ $10.1177 / 194008291500800208$.
Suazo-Ortuño, I., Lopez-Toledo, L., Alvarado-Díaz, J., Martínez-Ramos, M., 2015b. Landuse change dynamics, soil type and species forming mono-dominant patches: the case of pteridium aquilinum in a neotropical rain forest region. Biotropica 47, 18-26. https://doi.org/10.1111/btp.12181.

Tauro, A., Gómez-Baggethun, E., García-Frapolli, E., Chavero, E.L., Balvanera, P., 2018. Unraveling heterogeneity in the importance of ecosystem services: Individual views of smallholders. Ecol. Soc. 23 https://doi.org/10.5751/ES-10457-230411.

Teixeira, H.M., Cardoso, I.M., Bianchi, F.J.J.A., da Cruz Silva, A., Jamme, D., PeñaClaros, M., 2020. Linking vegetation and soil functions during secondary forest succession in the Atlantic forest. For. Ecol. Manage. 457, 117696. https://doi.org/ 10.1016/j.foreco.2019.117696.

Trilleras, J.M., Jaramillo, V.J., Vega, E.V., Balvanera, P., 2015. Effects of livestock management on the supply of ecosystem services in pastures in a tropical dry region of western Mexico. Agric. Ecosyst. Environ. 211, 133-144. https://doi.org/10.1016/ j.agee.2015.06.011.

van Breugel, M., Martinez-Ramos, M., Bongers, F., 2006. Community dynamics during early secondary succession in Mexican tropical rain forests. J. Trop. Ecol. 22, 663-674. https://doi.org/10.1017/s0266467406003452.

van der Sande, M.T., Poorter, L., Balvanera, P., Kooistra, L., Thonicke, K., Boit, A., Dutrieux, L.P., Equihua, J., Gerard, F., Herold, M., Kolb, M., Simões, M., PeñaClaros, M., 2017. The integration of empirical, remote sensing and modelling approaches enhances insight in the role of biodiversity in climate change mitigation by tropical forests. Curr. Opin. Environ. Sustain. 26-27 https://doi.org/10.1016/j. cosust.2017.01.016.

Villa-Issa, M.R., 1990. Performance of Mexican agriculture: the effects of economic and agricultural policies. Am. J. Agric. Econ. 72, 744-748. https://doi.org/10.2307/ 1243048.

Wies, G., Arzeta, S.N., Martinez-Ramos, M., 2021. Critical ecological thresholds for conservation of tropical rainforest in Human Modified Landscapes. Biol. Conserv. 255 https://doi.org/10.1016/j.biocon.2021.109023.

Wright, S.J., 2010. The future of tropical forests. Ann. New York Acad. Sci. 1195, 1-27. https://doi.org/10.1111/j.1749-6632.2010.05455.x.

Zermeño-Hernández, I., Méndez-Toribio, M., Siebe, C., Benítez-Malvido, J., MartínezRamos, M., 2015. Ecological disturbance regimes caused by agricultural land uses and their effects on tropical forest regeneration. Appl. Veg. Sci. 18, 443-455. https://doi.org/10.1111/avsc.12161.

Zermeño-Hernández, I., Pingarroni, A., Martínez-Ramos, M., 2016. Agricultural land-use diversity and forest regeneration potential in human- modified tropical landscapes. Agric. Ecosyst. Environ. 230, 210-220. https://doi.org/10.1016/j. agee.2016.06.007. 